Koji Okuhara $\cdot$ Toshihiro Tajima $\cdot$ Jun Nakae

Kenji Fujieda

\title{
A novel missense mutation in the HMG box region of the SRY gene in a Japanese patient with an $X Y$ sex reversal
}

Received: October 12, 1999 / Accepted: November 4, 1999

\begin{abstract}
The sex-determining region of the $\mathrm{Y}$ chromosome, the $S R Y$ gene, located on the short arm of the $\mathrm{Y}$ chromosome, is appreciated as one of the genes that is responsible for directing the process of sex differentiation. To date, 34 different mutations, including 29 missense and nonsense mutations in the $S R Y$ gene, have been described in XY female patients. We investigated the molecular basis of the sex reversal in one Japanese $\mathrm{XY}$ female patient by determining the nucleotide sequence of the $S R Y$ gene, using polymerase chain reaction and direct sequencing. We identified a novel mutation, of the substitution of Tyr for Asn at nucleotide position 87 (N87Y). This Asn residue is located within the DNA-binding high-mobility-group (HMG) motif, which is considered to be the main functional domain of the SRY protein. Further, this amino acid, Asn, is a conserved residue among mammalian $S R Y$ genes. These findings indicate that this amino acid substitution may be responsible for the sex reversal in this patient.
\end{abstract}

Key words 46, XY Female · Gonadal dysgenesis · SRY · HMG box $\cdot$ Missense mutation

\section{Introduction}

Identification of mutation(s) in the gene(s) that direct the process of sex differentiation in humans gives insights into the understanding of the molecular basis of sex differentiation. The gene for the sex-determining region of the $\mathrm{Y}$ chromosome $(S R Y)$ was the first gene identified in this process (Sinclair et al. 1990). This gene has a unique structure in which the deduced 80-amino acid region of the SRY protein shows high homology to a motif within the highmobility-group (HMG) proteins. This conserved motif,

K. Okuhara $\cdot$ T. Tajima $\cdot$ J. Nakae $\cdot$ K. Fujieda $(\square)$

Department of Pediatrics, Hokkaido University School of Medicine,

N15, W7, Kita-ku, Sapporo 060-8638, Japan

Tel. +81-11-716-1161 (ext. 5954); Fax +81-11-706-7898

e-mail: ken-fuiji@med.hokudai.ac.jp known as the HMG box, possesses sequence-specific DNAbinding activity and acts as a transcriptional regulator in the cascade of sex determination (Gubbay et al. 1990). The XY female is rare and is characterized by sexual infantilism, the absence of differentiated gonads (only streak gonads being present), and the presence of normally developed Mullerian structures, including uterus and fallopian tubes, in a phenotypic female with an XY karyotype. Approximately $15 \%$ of $\mathrm{XY}$ female phenotype patients harbor nonsense or missense mutations and deletion mutations of the $S R Y$ gene, which are mainly present within the HMG box (Hawkins et al. 1992a; Ferguson-Smith 1992). We experienced a phenotypic female patient presenting with abdominal tumor; molecular analysis identified a novel missense mutation within the HMG box of the SRY gene.

\section{Patient and methods}

Case history

A 12-year-old phenotypic female was referred to the Pediatric Department at Hokkaido University Hospital because of a right lower abdominal mass. She was $153 \mathrm{~cm}$ tall $(+0.65$ SD for normal Japanese female) and her weight was $35.9 \mathrm{~kg}$. She was born to healthy unrelated parents and had had an uneventful gestation period. She had been healthy until this visit, when an abdominal mass was observed. She had not manifested any secondary sexual characteristics at that time.

On examination, a $20 \times 18$-cm firm mass was palpated in the lower abdomen. The patients pubertal stage was B1, PH1 according to the Tanner stage. Abdominal computed tomography detected a right gonadal mass of $18 \times 11 \times$ $7 \mathrm{~cm}$, a left streak gonad, and prepubertal-size uterus. Endocrinological examination demonstrated extremely elevated basal plasma levels of follicle-stimulating hormone $(24.8 \mathrm{mIU} / \mathrm{ml}$; standard range for prepubertal teen-aged girl, 1.16-3.65 $\mathrm{mIU} / \mathrm{ml}$ ) and luteinizing hormone $(143.0 \mathrm{mIU} / \mathrm{ml}$; standard range for prepubertal teen-aged 


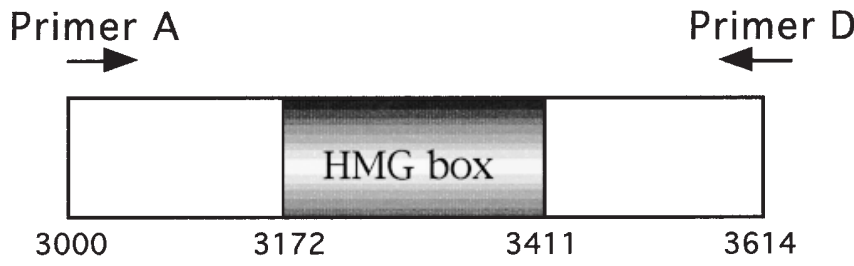

A: 5'-GAATATTCCCGCTCTCCGGAGAA-3'

A D: 5'-AGCTGGTGCTCCATTCTTGAGTG-3'

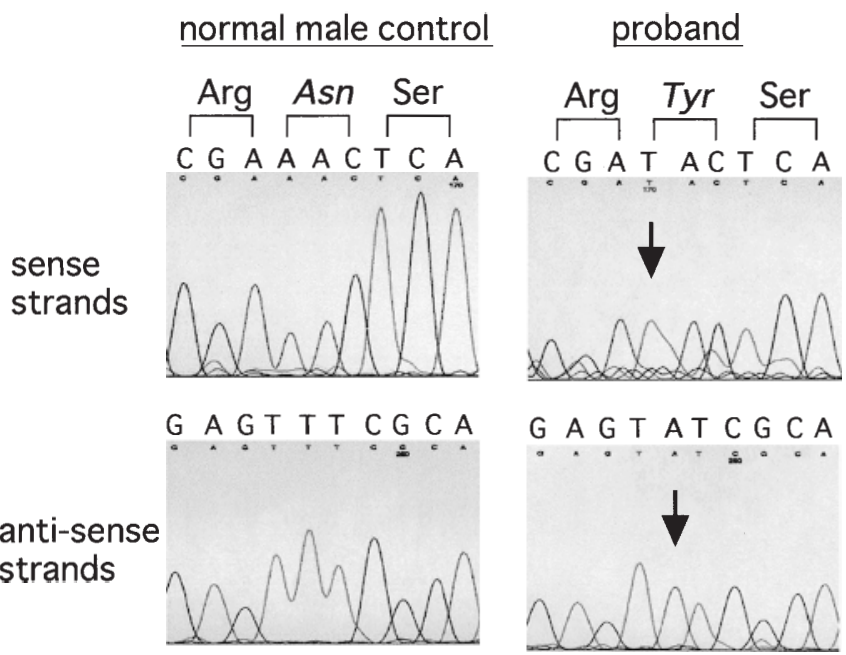

Fig. 1. A Location of oligonucleotides used for polymerase chain reaction and direct sequencing in the $S R Y$ gene. Numbers refer to GenBank Accession L08063 NID g347961. B Part of the nucleotide sequence of the $S R Y$ gene. Arrows indicate A-to-T nucleotide transition, resulting in amino acid substitution of Tyr for Asn. $H M G$, Highmobility-group (motif)

girl, $0.02-0.11 \mathrm{mIU} / \mathrm{ml})$. Her karyotype was 46 , XY. No mosaicism or structural anomalies of the $\mathrm{Y}$ chromosome were identified.

She underwent surgery for the resection of the right gonadal tumor and the left streak gonad. Histological examination revealed that the right gonadal mass was gonadoblastoma. Based on these findings, she was diagnosed as an XY female.

\section{DNA analysis}

Informed consent for DNA analysis was obtained from the patient's parents. DNA was prepared from white blood cells, using standard techniques. Primers for polymerase chain reaction (PCR) were selected in the SRY region to flank the entire motif of the HMG box, as described previously (Tajima et al. 1994) (Fig. 1A). PCR and direct sequencing of PCR products were performed using a Dye Terminator Amplitaq FS kit (Applied Biosystems, Foster City, CA) and analyzed with an ABI 373A automated sequencer (Applied Biosystems), according to a previous method (Nakae et al. 1996).

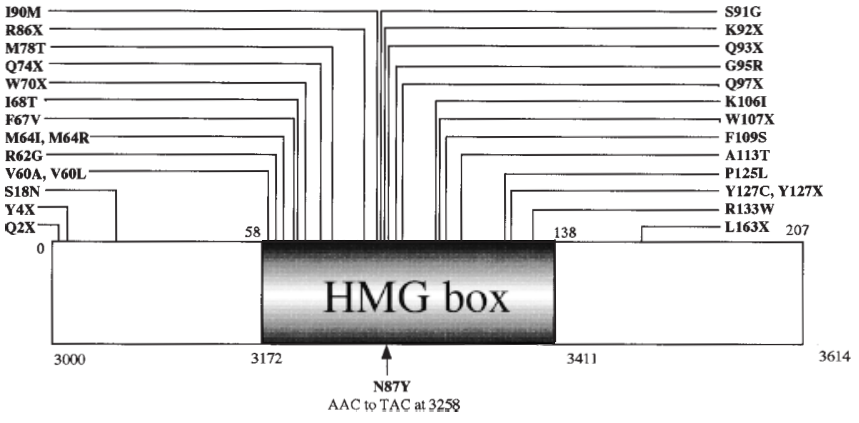

Fig. 2. The $S R Y$ gene and its nonsense and missense mutations. The black bar indicates the HMG box. The nonsense and missense mutations of the $S R Y$ gene reported previously are shown above the schema of the $S R Y$ gene. The mutation within the HMG box in our patient is shown by the arrow below the schema of the $S R Y$ gene

The protocol was approved by the institutional review board.

\section{Results}

Direct sequencing revealed the transition of adenine (A) nucleotide to thymine $(\mathrm{T})$ at nucleotide position 3,258 within the HMG box (Fig. 1B). By this nucleotide transition, codon AAC [Asn (N)] at amino acid position 87 changed to TAC $[\operatorname{Tyr}(\mathrm{Y})]$. This nucleotide transition was not detected in DNA from the patient's parents, indicating that this was a de-novo mutation. To rule out that the possibility that this mutation was not merely a polymorphism, we analyzed the $S R Y$ gene in 50 unrelated normal Japanese males by PCR-direct sequencing. This mutation was not present in any of these control samples.

\section{Discussion}

We identified a novel missense mutation (N87Y) within the HMG box of the $S R Y$ gene in our Japanese patient with XY sex reversal with gonadoblastoma. To date, 29 unique missense and nonsense mutations of the $S R Y$ gene have been reported in XY female patients (Fig. 2) (Hawkins et al. 1992a; Hawkins et al. 1992b; McElreavy et al. 1992a, McElreavy et al. 1992b; Muller et al. 1992; Affara et al. 1993; Jager et al. 1993; Hawkins 1993; Schmitt-Ney et al. 1993; Zeng et al. 1993; Iida et al. 1994; Poulat et al. 1994; Tajima et al. 1994; Hiort et al. 1995; Bilbao et al. 1996; Cameron and Sinclair 1997; Veitia et al. 1997; Brown et al. 1998; Domenice et al. 1998; Scherer et al. 1998). Most of these mutations are located within the HMG box domain in the SRY gene, which has a sequence-specific DNA-binding activity. This HMG box has a critical function as a transcriptional regulator in the cascade of sex determination (Werner et al. 1995). The N87Y mutation identified in our patient is also located in the HMG box. While the 
Asn at codon 87 is not strictly conserved among the different HMG domain proteins, it is the most frequently found residue at this position. Thus, this Asn is presumed to be important for the normal function of SRY protein. The two mutations of I90M and S91G have also been detected near N87Y in XY female patients (Hawkins et al. 1992b; Schmitt-Ney et al. 1993). These two mutants are localized in helix 2 in the deduced tertiary structure of rat and hamster HMG1 (Read et al. 1993; Weir et al. 1993). One of these mutants, S91G, was shown to manifest reduced DNAbinding activity by an in-vitro expression study (SchmittNey et al. 1993). Since N87Y is also located in helix 2, like I90M and S91G, these three mutants would, presumably, have similar biological functions, by disturbing the SRYDNA interaction. Thus, it is most plausible that this mutation is responsible for the sex reversal in our patient, whereas the function of mutated SRY N87Y protein remains to be determined.

It is known that XY females have a risk of developing tumors of gonadal origin (Ferguson-Smith 1991). Gene(s) other than the $S R Y$ gene are suspected to responsible for the pathophysiology of gonadoblastoma, although the gene(s) are not yet cloned. Our patient already had a gonadoblastoma at the age of 12 years. Therefore, it is recommended that XY females should be identified prepubertally, because delayed diagnosis may bring about the development of a gonadal tumor.

\section{References}

Affara NA, Charmers IJ, Ferguson-Smith MA (1993) Analysis of the $S R Y$ gene in 22 sex-reversed $\mathrm{XY}$ females identifies four new point mutations in the conserved DNA binding domain. Hum Mol Genet 2:785-789

Bilbao JR, Loridan L, Castano L (1996) A novel postzygotic nonsense mutation in $S R Y$ in familial $\mathrm{XY}$ gonadal dysgenesis. Hum Genet 97:537-539

Brown S, Yu CC, Lanzano P, Heller D, Thomas L, Warburton D, Kitajewski J, Stadtmauer L (1998) A de novo mutation (Gln2Stop) at the 5-prime end of the $S R Y$ gene leads to sex reversal with partial ovarian function. Am J Hum Genet 62:189-192

Cameron FJ, Sinclair AH (1997) Mutations in SRY and SOX9: testisdetermining genes. Hum Mutat 9:388-395

Domenice S, Nishi MY, Billerbeck A EC, Latronico AC, Medeiros MA, Russell AJ, Vass K, Carvalho FM, Frade EMC, Arnhold IJ P, Mendonca BB (1998) A novel missense mutation (S18N) in the 5prime non-HMG box region of the $S R Y$ gene in a patient with partial gonadal dysgenesis and his normal male relatives. Hum Genet 102:213-215

Ferguson-Smith MA (1991) Genotype-phenotype correlations in individuals with disorders of sex determination and development including Turner's syndrome. Semin Dev Biol 2:265-276

Ferguson-Smith MA (1992) Clinical contributions towards understanding the genetics of sex differentiation. In: Hughes IA (ed) Sex differentiation: clinical and biological aspects (frontiers in endocrinology). Serono Symposia Publications, Cambridge, UK, pp 5-12

Gubbay J, Collignon J, Koopman P, Capel B, Economou A, Munsterberg A, Vivian N, Goodfellow P, Lovell-Badge R (1990) A gene mapping to the sex-determining region of the mouse $Y$ chromosome is a member of a novel family of embryonically expressed genes. Nature 346:245-251
Hawkins JR, Taylor A, Berta P, Levilliers J, Auwera BV, Goodfellow PN (1992a) Mutational analysis of $S R Y$ nonsense and missense mutations in XY sex reversal. Hum Genet 88:471-474

Hawkins JR, Taylor A, Goodfellow PN, Migeon CJ, Smith KD, Berkovitz GD (1992b) Evidence for increased prevalence of $S R Y$ mutations in XY females with complete rather than partial gonadal dysgenesis. Am J Hum Genet 51:979-984

Hawkins JR (1993) Mutational analysis of $S R Y$ in XY females. Hum Mutat 2:347-350

Hiort O, Gramss B, Klauber GT (1995) True hermaphroditism with $46, X Y$ karyotype and a point mutation in the $S R Y$ gene. J Pediatr 126:1022

Iida T, Nakahori Y, Komaki R, Mori E, Hayashi N, Tsutsumi O, Taketani Y, Nakagome Y (1994) A novel missense mutation in the HMG box of the $S R Y$ gene in a patient with XY sex reversal. Hum Mol Genet 3:1437-1438

Jager RJ, Harley VR, Preiffer RA, Goodfellow PN, Scherer G (1993) A familial mutation in the testis-determining gene $S R Y$ shared by both sexes. Hum Genet 90:350-355

McElreavy KD, Vilain E, Abbas N, Costa JM, Souleyreau N, Kucheria K, Boucekkine C, Thibaud E, Brauner R, Flamant Fellous M (1992a) XY sex reversal associated with a deletion $5^{\prime}$ to the $S R Y$ "HMG box" in the testis-determining region. Proc Natl Acad Sci USA 89:11016-11020

McElreavey KD, Vilain E, Boucekkine C, Vidaud M, Jaubert F, Richaud F, Fellous M (1992b) XY sex reversal associated with a nonsense mutation in SRY. Genomics 13:838-840

Muller J, Schwartz M, Skakkebaek NE (1992) Analysis of the sexdetermining region of the Y-chromosome (SRY) in sex reversed patients: point-mutation in $S R Y$ causing sex-reversion in a $46, \mathrm{XY}$ female. J Clin Endocrinol Metab 75:331-333

Nakae J, Tajima T, Kusuda S, Kohda N, Okabe T, Shinohara N, Kato M, Murashita M, Mukai T, Imanaka K, Fujieda K (1996) Truncation at the C-terminus of the DAX-1 protein impairs its biological actions in patients with X-linked adrenal hypoplasia congenita. J Clin Endocrinol Metab 81:3680-3685

Poulat F, Soullier S, Goze C, Heitz F, Calas B, Berta P (1994) Description and functional implications of a novel mutation in the sexdetermining gene SRY. Hum Mutat 3:200-204

Read CM, Cary PD, Crane-Robinson C, Driscoll PC, Norman DG (1993) Solution structure of a DNA-binding domain from HMG1. Nucleic Acids Res 21:3427-3436

Scherer G, Held M, Erdel M, Meschede D, Horst J, Lesniewicz R, Midro AT (1998) Three novel SRY mutations in XY gonadal dysgenesis and the enigma of $\mathrm{XY}$ gonadal dysgenesis cases without $S R Y$ mutations. Cytogenet Cell Genet 80:188-192

Schmitt-Ney M, Thiele H, Kaltwaber P, Bardoni B, Cisternino M, Scherer G (1993) Two novel $S R Y$ missense mutation reducing DNA binding identified in XY females and their mosaic father. Am J Hum Genet 56:862-869

Sinclair AH, Berta P, Palmer LS, Howkins JR, Griffiths BL, Smith MJ, Foster JW, Frischauf AM, Lovell-Badge R, Goodfellow PN (1990) A gene from the human sex-determining region encodes a protein with homology to a conserved DNA-binding motif. Nature 346:240-244

Tajima T, Nakae J, Shinohara N, Fujieda K (1994) A novel mutation localized in the $3^{\prime}$ non-HMG box region of the $S R Y$ gene in $46, \mathrm{XY}$ gonadal dysgenesis. Hum Mol Genet 3:1187-1189

Veitia R, Ion A, Barbaux S, Jobling MA, Souleyreau N, Ennis K, Ostrer H, Tosi M, Meo T, Chibani J, Fellous M, McElreavey K (1997) Mutations and sequence variants in the testis-determining region of the $\mathrm{Y}$ chromosome in individuals with a 46,XY female phenotype. Hum Genet 99:648-652

Werner MH, Huth JR, Gronenborn AM, Clore GM (1995) Molecular basis of human $46 \mathrm{X}, \mathrm{Y}$ sex reversal revealed from the threedimensional solution structure of the human SRY-DNA complex. Cell 81:705-714

Zeng Y, Ren Z, Zhang M, Huang Y, Zeng F, Huang S (1993) A new de novo mutation (A113T) in HMG box of the $S R Y$ gene leads to XY gonadal dysgenesis. J Med Genet 30:655-657

Weir HM, Kraulis PJ, Hill CS, Raine ARC, Laue ED, Thomas JO (1993) Structure of the HMG box motif in the B-domain of HMG1. EMBO J 12:1311-1319 